\title{
Sexed Semen Technique: A Revolution in Indian Dairy Industry
}

\section{Khaja Mohteshamuddin*}

Department of Veterinary Medicine, College of Food \& Agriculture, United Arab Emirates University, Al-Ain, United Arab Emirates

*Corresponding author: Khaja Mohteshamuddin, Instructor, Department of Veterinary Medicine, College of Food \& Agriculture, United Arab Emirates University, Al-Ain, United Arab Emirates, Tel: 00971-561509808; E-mail: drkhaja707@uaeu.ac.ae

Received date: September 22, 2017; Accepted date: September 26, 2017; Published date: Octoberber 03, 2017

Copyright: (c) 2017 Mohteshamuddin K. This is an open-access article distributed under the terms of the Creative Commons Attribution License, which permits unrestricted use, distribution, and reproduction in any medium, provided the original author and source are credited.

\section{Introduction}

India is unique in its appreciation of the cow culturally with less than $40 \%$ of India's cows productive. This coupled with high milk demand renders the male calf not productive and thus non-required and are often castrated early in life and mostly left unattended.

Sexed semen is simply as the name states, semen that has been separated to contain sperm that will most likely produce a male or female offspring. In today's dairy industry, producers need to implement strategies that will produce results and help them gain a competitive edge in their market. Using sexed semen is one such strategy, that, when used properly on a dairy, can help farmers grow their herds internally. As small farms are converted into larger operations, there are a number of issues that must be dealt with in order to achieve a smooth transition. Taking advantage of sexed semen technology, heifers will be born as often as $95 \%$ of the time, instead of $49 \%$ of the time when using semen that is not sorted for sex Figure 1.

\section{Technique of Sperm Separation into Male and Female Bearing Sperm}

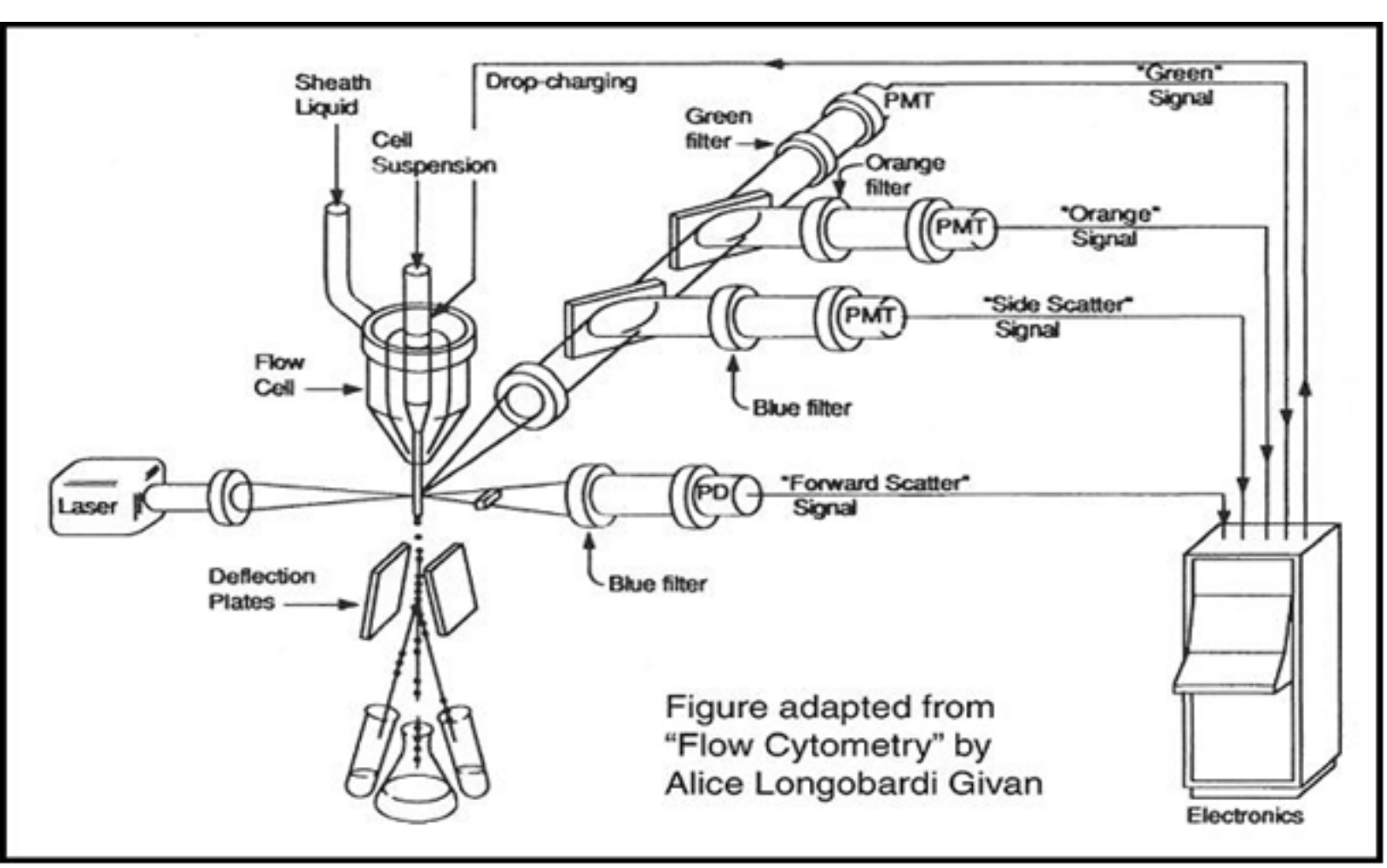

Figure 1: Technique of sperm separation into male and female bearing sperm.

Semen is actually sorted one sperm at a time and yield is low. Sperm with an $\mathrm{X}$ chromosome (which results in females) has slightly more DNA than Y-bearing sperm (which result in males). The sperm are treated with a fluorescent die that allows differentiation of the amount of DNA in the sperm. Sperm are then diluted and placed in droplets so each individual sperm is in a droplet. The droplets enter the detector where a laser is used to energize the dye during the sorting process the machine identifies the sperm as $\mathrm{X}$ or $\mathrm{Y}$, and it puts a charge on the drop that the sperm is placed in for sorting. An electrical field deflects the sperm towards the collection vessel. The sperm hit the fluid in the collection vessel at about $50 \mathrm{kph}(30 \mathrm{mph})$. The sorted sperm are the centrifuged and re-suspended. Although the sorting process is $90 \%$ accurate, approximately half the sperm cannot be sorted because they are damaged or the machine could not determine $\mathrm{X}$ or Y. Therefore, $50 \%$ of the ejaculate is discarded. 
Citation: Mohteshamuddin K (2017) Sexed Semen Technique: A Revolution in Indian Dairy Industry. Agrotechnology 6: e117. doi: 10.4172/2168-9881.1000e117

Page 2 of 2

There are more advantages to using sexed semen in the dairy industry than the beef industry, but both can benefit from the implementation. Dairy operations can use sexed semen for the production of replacement daughters from genetically superior cows. Dairy producers can also use superior sexed semen for the production of bulls for progeny testing from the population of elite dams. In doing this, the cost of progeny testing those bulls is drastically reduced because of the decreased need for more mating to ensure superior daughters.

\section{Indian Scenario of this Technique and Availability in India}

Sexed semen was sorted and marketed in foreign countries at a very high price in the past few years. Countries like USA, New Zealand,
Denmark \& Australia had been using commercial sexed semen since few years. Off late, sexed semen straws containing only female genes are available in India in recent months, to exploit its benefits this technology had also been capped by the animal husbandry department, government of India, which is making available sexed semen straws at the field level for insemination purpose. Farmers can make use of this technique at an affordable and subsidized cost in some Indian states. A dairy farmer, who doesn't want to maintain any Bull, can find this technique very handy. Those interested to benefit from this can visit your nearest veterinary hospital or dispensary for more information. 